\title{
A boring foraminiferan from the Upper Jurassic of England and Northern France
}

\author{
C.R. PLEWES \\ Department of Earth Studies, \\ University of Wales, \\ Aberystwyth, Dyfed SY23 3DB \\ U.K.
}

\author{
T.J. PALMER \\ Department of Earth Studies, \\ University of Wales, \\ Aberystwyth, Dyfed SY23 3DB \\ U.K.
}

\author{
J.R. HAYNES \\ Department of Earth Studies, \\ University of Wales, \\ Aberystwyth, Dyfed SY23 \\ U.K.
}

\begin{abstract}
Small rosette borings, consisting of an excavated pit from which is subtended a system of branching galleries, are common in carbonate skeletal substrates in the Upper Jurassic Oxford Clay (CallovianOxfordian) and Kimmeridge Clay (Kimmeridgian) of southern England and northern France. The opening of the pit onto the substrate surface is surrounded by an agglutinated collar, which suggests that they may be the work of Foraminifera. The new genus and species, Globodendrina monile, are erected to accommodate them. Other examples of boring in the Foraminiferida are reviewed. It is proposed that other similar rosette boring ichnogenera may also be the work of foraminiferans. J. Micropalaeontol., 12 (1): 83 89, August 1993.
\end{abstract}

\section{INTRODUCTION}

Small rosette-borings, of the order of a millimetre or two across, are commonly encountered in fossil shells and other hard calcareous substrates (Häntzschel, 1975; Vogel et al., 1987). Earlier studies based descriptions on gross characters such as the overall shapes of the borings themselves, whereas more recent studies have usually employed the technique of impregnating the borings with epoxy resin and dissolving away the substrate. Such artificial casts can be studied under the SEM, and yield much more micromorphological information than can be seen in the borings themseves. Consequently, some earlier taxonomic descriptions are considered by many workers to be insufficiently detailed for modern usage.

Rosette borings up to $c$. $1 \mathrm{~mm}$ across are very common in shells of the large oyster Gryphaea from the Oxford Clay (Callovian-Lower Oxfordian; Upper Jurassic) of southern England and northern France (Fig.1; Pl. 1). The same form also occurs in the upper Oxfordian-Lower Kimmeridgian oyster, Deltoideum delta. Many specimens of the borings are abraded (Pl.1, fig. 8) and show up as a pattern of radiating etched canals in the shell surface. Well-preserved specimens, however, show a small sub-central hole leading into a chamber, which in turn subtends from one side a series of radiating canals excavated just below the surface (P1. 1, fig. 4). In the best-preserved examples (much less than $1 \%$ of the total number of specimens examined), a small agglutinated chimney rises from the surface around the entrance hole (Fig. 1A, Pl. 1, figs 1-3). The presence of this chimney and the small size of the overall structure suggests that they may have been produced by foraminiferans.

\section{METHODS}

Specimens were located using a binocular microscope and cut from the host shell using a diamond saw. The pieces of shell were ground to size, mounted on SEM stubs and gold/palladium coated. Other specimens were impregnated with epoxy resin, and the shell was dissolved away in dilute hydrochloric acid after the resin had hardened (Fig. 1B, Pl.1, figs 5-7). these artificial casts were then mounted, coated, and examined in the SEM in the normal way.

\section{SYSTEMATIC PROCEDURE}

The majority of specimens of the putative foram described here consist only of the rosette boring. As borings, they can, like other rosette borings, be treated as trace-fossils and described as ichnospecies. Complete specimens, however, consist of both the excavation and the agglutinated chimney, and we prefer to treat them as body fossils. Even in the absence of the chimney, the boring is likely to reflect accurately the morphology of the soft parts that filled it in life. Borings of other groups that are accurate moulds of the soft parts (e.g. ctenostome bryozoans - see Pohowsky, 1978) are also sometimes named as body rather than trace fossils.

\section{SYSTEMATIC DESCRIPTIONS}

Order Astrorhizida

Family Astrorhizidae Brady, 1881

Globodendrina gen. nov.

Derivation of name. globus (L.) = globe; dendron (Gr.) = tree, with reference to the branches issuing from a globular chamber.

Diagnosis. Small (1-2mm across) boring in carbonate substrate, consisting of fan-like branching tunnel system 

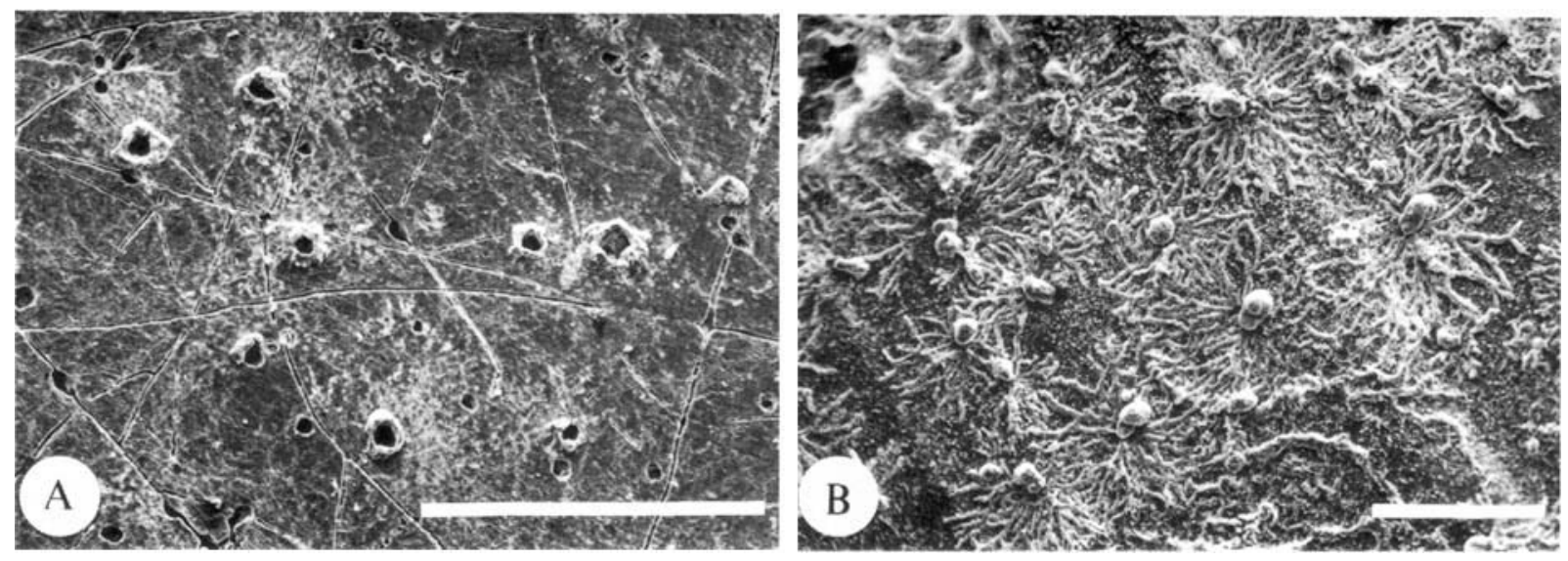

Fig. 1 Populations of Globodendrina monile gen. et sp.nov. on Gryphaea. Scale Bars $=1 \mathrm{~mm}$. A. Individuals which mostly show chimneys. Threadlike borings were made by Bryozoa. Lower Oxford Clay, Vaches Noires, Normandy. OUM JZ2240. B. Epoxy-resin infills to show variation in size and shape. Lower Oxford Clay, Bletchley Brickworks, Buckinghamshire. OUM J53275.

issuing from one side of globular chamber (Pl. 1 figs 4,5) Main branches are more or less circular in cross-section and subtend finer branches, of which upward-directed ones open onto substrate surface (P1. 1, figs 5,7). Main chamber with single opening to surface, surrounded by conical agglutinated chimney of well-sorted fine silt particles in cement.

Type species. Globodendrina monile sp.nov.

Remarks. The association of a small rosette boring with an agglutinated chimey has not been previously described. The boring resembles the ichnogenera Ramodendrina and Nododendrina of Vogel, Golubic \& Brett (1987), but differs from the former in the presence of the globular chamber and from the latter by the circular cross-section of the branches.

Several workers have previously noted and illustrated similar borings from shell material of a variety of ages, but none of them has provided the sort of detailed information that comes from casting and we are therefore unable taxonomically to integrate their studies with ours. BernardDumanois \& Delance (1983) described material from the Bajocian of Burgundy and ascribed it to endolithic green algae similar to Recent Codiolum polyrhizum, which Kornmann (1969) showed to be the sporophyte stage of Gomontia polyrhiza. The size range of their material, however, is more similar to that of G. monile than to $C$. polyrhizum (Bernard-Dumanois \& Delance, 1983, fig.4). Higazi (1985) also interprets similar material from the Upper Oxfordian of Spain as having affinities with $C$. polyrhizum, though one of his illustrations (Higazi, 1985, fig.13) appears to be a straight copy of Bernard-Dumanois \& Delance's (1983) Bajocian material. Pliocene material described by Mayoral (1988) from south-west Spain and also ascribed to algae is somewhat similar to our material in general shape, but only about one quarter of the size.

Cherchi \& Schroeder (1991) describe Recent material from Scotland in which the endolithic part of the construction looks very similar to G. monile in size and shape. Agglutinating chimneys are absent, but a very few of their examples show, within the main chamber, an involutely coiled foram which they assume is responsible for the borings. We think that, were this so, then the enclosed tests would be much more common given that they would have been protected from damage and erosion within the cavity. More likely, they were secondary nestlers. Although coiled foraminiferan tests are unknown from any similar ancient borings, on the basis of their Scottish material Cherchi \& Schroeder (1991) also inferred a foraminiferal origin for the material described by BernardDumanois \& Delance (1983) and by Higazi (1985), as

\section{Explanation of Plate 1}

Figs 1-8 Globodendrina monile gen. et sp.nov. Fig.1. Oblique view of agglutinated chimney of holotype on Gryphaea shell. Lower Oxford Clay, Stanton Harcourt, Oxfordshire. OUM J53263. Scale Bar $=100 \mu \mathrm{m}$; Fig. 2. Agglutinated chimneys of a pair of paratypes showing variation in size of individuals preserved. Lower Oxfordian, Vaches Noires, Normandy. OUM JZ2240. Scale Bar $=100 \mu$ m; Fig. 3. Close-up of agglutinated chimney wall of holotype (Fig.1) showing details of size and orientation of particles. Lower Oxford Clay, Stanton Harcourt, Oxfordshire. OUM J53263. Scale Bar $=20 \mu \mathrm{m}$; Fig. 4. Individual whose chimney has been removed to reveal hole leading into the chamber. Bright pattern picks out fine perforations which connect to the underlying tunnel system. Lower Oxfordian, Vaches Noires, Normandy. OUM JZ2240. Scale Bar $=200 \mu \mathrm{m}$; Fig. 5. Epoxy resin infill of complete boring. Lower Oxford Clay, Bletchley Brickworks, Buckinghamshire. OUM J53275. Scale Bar $=200 \mu \mathrm{m}$; Fig. 6. Detail of chamber to show papillate ornament (same specimen as Fig.5). Lower Oxford Clay, Bletchley Brickworks, Buckinghamshire. OUM J53275. Scale Bar $=50 \mu \mathrm{m}$; Fig. 7. Detail of tunnel resin casts (viewed from underneath) showing fine connections to overlying surface. Lower Oxford Clay, Bletchley Brickworks, Buckinghamshire. OUM J53275. Scale Bar = 100 $\mu \mathrm{m}$; Fig. 8. Eroded boring in which tunnels have been exposed by the removal of superficial shell material. Lower Oxfordian, Vaches Noires, Normandy. OUM JZ2240. Scale Bar $=200 \mu \mathrm{m}$. 

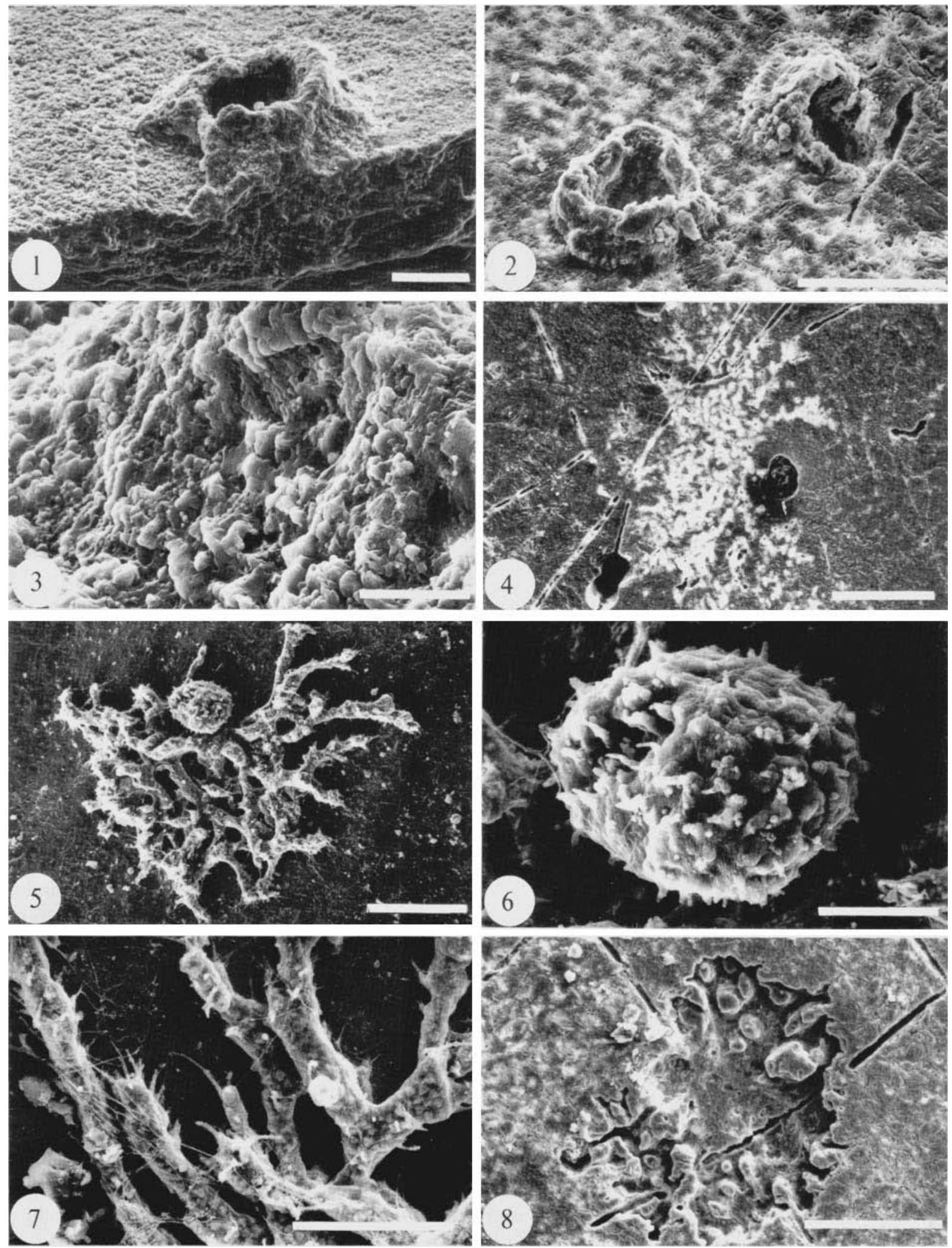
discussed above. They also suggest that boring by foraminiferans may be of greater importance in both Recent and ancient marine carbonate substrates than has hitherto been appreciated. Although we think that they have been led to this view down the wrong path, it is a view with which we strongly concur! A study that sets out to distinguish between true Gomontia /Codiolum borings and those of a probable foraminiferal origin is well overdue, given the importance of such structures in the bioerosion of shells both in the Recent (e.g. Boekschoten, 1966) and in the geological record.

Amongst agglutinating foraminiferan genera, the Holocene Notodendrodes has a bulbous central portion with upward-projecting tree-like branches and a downwardbranching root-like holdfast, but the whole test is aglutinated and the holdfast is buried in soft sediment, not excavated by boring.

\section{Globodendrina monile sp. nov.}

(Pl. 1, figs 1-8; Fig. 1)

Derivation of name. monile $(\mathrm{L})=$. collar, referring to the agglutinated chimney

Diagnosis. Chimney. Cross-sectional shape roughly circular; tapered from diameter of up to $c .150 \mu \mathrm{m}$ at base to c. $75 \mu \mathrm{m}$ at a height of $c$. $60 \mu \mathrm{m}$. Chamber. Spherical or lobate, $c .100-200 \mu \mathrm{m}$ in diameter, excavated to a depth of $c$. $200 \mu \mathrm{m}$ below surface. Surface covered in small excavatory papillae. Tunnels. Arise from one or more points on one side of chamber; divide by bifurcation or trifurcation in horizontal plane, maintaining distance of c. 20-30 $\mu \mathrm{m}$ below surface; occasional branches descend vertically; division spacing c.40-140 $\mu \mathrm{m}$; bifurcation angle c. 50-90 degrees; tunnels somewhat bulbous along length, but maintaining more or less circular cross-section, c. $15-30 \mu \mathrm{m}$ diameter; may interlink in older (more proximal) region; endings blunt; surfaces covered with smaller, papilla-like and filamentous branches, particularly on upper sides where they open through tiny pores onto substrate surface.

Type Material. Oxford University Museum (OUM) Collections. Holotype: J.53250; paratypes: J.53251-J.53286. Localities and Horizons. J.53250-J.53286; Lower Oxfordian, collected from loose Gryphaea derived from the Marnes de Villers; Flaises des Vaches Noires, c. $1 \mathrm{~km}$ east of Houlgate, Calvados, Normandy, France. J.53263-J.53274; Callovian, collected from loose Gryphaea derived from Lower and Middle Oxford Clay; Stanton Harcourt, Oxon (SP 408045). J.53275-J.53280; Callovian, collected from loose Gryphaea derived from Lower Oxford Clay; Bletchley Brick Pit, Bucks (SP 862325). J.53281-J.53285; Callovian, collected from loose Gryphaea derived from Lower and Middle Oxford Clay; Cleveland Farm Quarry, Ashton Keynes, Wilts (SU 070948). Variation. Detailed morphology is influenced by the contours of the substrate. Larger specimens with a more extensive gallery system have a larger collar, implying that the collar may be subject to modification during growth, and specimens growing in depressions on the substrate surface may show much longer collars than average. Some individuals show what may be the remnants of a septum within the lumen of the collar, but it is not clear whether the collar is ever subdivided into more than one chamber. Smaller individuals have a single, globular, initial chamber (which was presumably the main reservoir of cytoplasmic material), whereas larger specimens tend to display a more multilobed chamber (Fig. 1B). Larger chambers show more than one point of departure for the gallery system; these always lie on the same side, from which the tunnels fan out. The tendency for adjacent tunnels to interdigitate and anastomose in the more proximal parts of the tunnel system is more marked in older, larger specimens.

Remarks. Papillae and fine filamentous outgrowths from the walls of the main chamber and the tunnels (Pl.1, figs 6,7) may represent sensory excavations that allowed the animal to orientate itself within the substrate, maintaining a constant depth below the surface and avoiding interpenetration with neighbours; even when individuals are very densely clustered, their tunnels seem to avoid each other and not intergrow. The upper-surface filaments which open onto the substrate surface probably allowed passage of fine filopodia. Pseudopodia probably also issued from the collar.

We interpret the collar as an evolutionary remnant of the test, implying descent from a non-boring agglutinating ancestor. Possibly it would represent the most robust remnant of a more extensive network of agglutinated sheaths which offered protection to individual pseudopodia, as is seen in Recent Cibicides refulgens (Alexander \& DeLaca, 1987; see discussion below). Even bioimmured specimens which were overgrown in life by neighbouring serpulids and oysters, however, only show the collar; finer, more fragile agglutinated structures appear to be absent.

We see the function of the boring habit as primarily offering protection against abrasion and grazing by potential predators. It is possible that the animal obtained some nutrient from organic matter in the substrate (either shell proteins or other borers), but the presence of fine holes allowing passage of filopodia above the substrate surface suggests that this was not the principal mode of feeding. We strongly suspect that other small rosette borings, particularly the ichnogenera Nododendrina, Ramodendrina, and Platydendrina, may also represent the work of forams. Primary descriptions of these forms (Vogel et al. 1987) were made from epoxy casts, and further material should be examined for signs of associated agglutinated structures.

\section{DISCUSSION OF BORING WITHIN THE FORAMINIFERA}

Boring is known in several examples of fossil and Recent forams. The extent to which boring activity has modified the life habit of the foram is variable. Some bore with limited parts of the cytoplasm, mainly to provide anchorage for the test; others seem to have become totally embedded in their chosen substrate. In all these examples the ability to bore has not caused loss of the test.

Forams that anchor the test by boring with the pseudopodia include the Tertiary Vasigiobulina (Poag, 1969, 
1971), of which the type species $V$. alabamensis is found attached to mollusc shells, barnacle plates, and encrusting cheilostome bryozoans. The genus belongs to the Polymorphinidae, a family notorious for the plasticity of the test shape and fistulose outgrowths from the attachment chamber. $V$. alabamensis wedges itself securely into the calcium carbonate substrate with anchoring spines from the test. This is achieved by the dissolution of the shell around the spines so that they not only project into the shell fragment, but have enlarged distal ends which resemble an hourglass in shape. Poag (1971) suggests that the calcium carbonate used in the construction of these spines is that removed by the pseudopodia in the extension of the excavation to accommodate the spines themselves. These spines of attachment serve to brace the foram against the currents in the epifaunal environment and may also serve to augment passive food capture by acting as a framework for the pseudopodia. Attachment must have postdated death of the host, as perforated mollusc shells do not show a secretory response. Time of attachment with respect to the lifespan of the foraminiferan is not known.

Pozaryska \& Voigt (1985) have also discussed the attachment of polymorphinid forams to Bryozoa. The method of attachment used is not elucidated but is probably similar to that used by $V$. alabamensis. This habit of attachment causes much confusion in the identification of the individual polymorphinid specimens as the fistulose chamber of the foram is highly variable and "the shape of the fistulose projections depends solely on the character of the substrate to which a given individual is attached" (Pozaryska \& Voigt, 1985, p.157). They concluded that the attached Foraminifera could be considered neither as symbionts nor parasites of the bryozoan, but were simply epibiontic organisms trying to protect themselves against waves or currents by attaching themselves to suitable substrates. In most cases the points of attachment observed were on hard parts of the bryozoan colony that did not allow an intra vitam relationship to be inferred. One specimen showed the holdfast of the foram ending where the frontal membrane of the living bryozoan would have been, implying a life association.

Foraminifera that were able to create almost complete 'crypts' for themselves were first documented by HeronAllen (1915). Cymbalopora tabellaeformis within their crypts were collected from two shell fragments in a net trawl off the coast of the Kerimba Archipelago. Heron-Allen noted that the crypts have a number of radiating passages emanating from them, extending in all directions into the substance of the molluscan shell. He concluded that they accommodated the extruded pseudopodia. These foraminifera obviously spent a large proportion of their lives in these crypts as the opening of the crypt was always smaller than the diameter of the inhabnitant. This species has been studied more recently by Matteucci $(1974,1980)$ who illustrated the foraminiferans sunk within their crypts using SEM photographs. He also noted the great abundance of specimens living in this way on a variety of substrates: mollusc shells, dead corals, pieces of dead alga and other skeletal debris. He speculated that the reason for this cryptic way of life is to gain protection from both the high energy environment and predation.

Venec-Peyre $(1985,1987)$ has also noted the ability of a number of Recent foraminiferans to bore into sediment grains. She studied material from French Polynesia, and identified the agglutinated Rotaliammina sp. and Siphotrochammina sp. The calcareous species were referred to the Tretomphalus-Cymbaloporetta group and the taxonomic problems with this group were noted. She notes that both calcareous and agglutinated species 'build their own cavity' but speculates that the method of boring may differ as the cavities produced also differ. In the case of the agglutinated species the 'dissolution of the substrate seems to be incomplete and leads to the weakening of the carbonate framework into a number of minute aggregates' which are then secondarily gathered on the organic lining and cemented by the cell. The calcareous species, in contrast, seem to dissolve the matrix in a more complete manner, leaving a cavity with a fragile-looking outline.

The capacity of the Foraminifera to bore in a limited way has been studied by DeLaca \& Lipps (1972), who documented the ability of Rosalina globularis to create pits in substrates such as calcareous algae, crustacean carapaces and mollusc shells. Pitting of the calcareous alga Corallina officinalis is locally extensive enough to have eroded the top layers of the cortical cells so making the areas of attachement easily distinguishable from the normal outer surface of the alga. The mode of attachment consists of an organic membrane that is attached to both the substrate and the parts of the test in contact with it. A number of reasons have been put forward to account for the pitting ability of the forams. Todd (1965) considered it most unlikely the related species $R$. carnivora derived nutrition from the mantle cavity of the host molluscs, but suggested that it used the calcium carbonate derived from the shell to secrete its own test. DeLaca \& Lipps (1972), however, considered this to be unlikely for $R$. globularis, as specimens from rocks and other non-calcareous substrates have sound tests and $\mathrm{CaCO}_{3}$ is at saturation levels in shallow marine waters.

Some other foraminiferans have the capacity to bore in a more invasive capacity An unusual example of a foraminiferan that seems to have bored into another member of the group is that described by Baumfalk, Fortuin \& Mok (1982). This involves the small Talpinella cunicularia found in the equatorial plane of the Upper Cretaceous Orbitoides. In a collection of 3,000 specimens, $80 \%$ were bored by $T$. canicularia and some hosts showed evidence of boring by more than one individual. The inside of the tunnels created by the boring action of the forams is smooth and so indicative of selective dissolution of the calicte. The test of $T$. canicularia is completely encased within the test of the Orbitoides, having gained entry via its equatorial or lateral layers. Whether this relationship between the two species was parasitic or, as Baumfalk et al. (1982) suggest, merely a post mortem 'hermitic' habit of $T$. canicularia, 
remains open to dispute. If the latter was adapted to inhabit the empty test of Orbitoides it may have mimicked its life style whilst taking advantage of the shelter afforded by its more massive test. This interpretation also seems likely as Baumfalk et al. (1982, p.190) note that the amount of food obtainable from one dead or living orbitoid is too small to sustain the metabolism of a sizable foraminiferan like $T$. canicularia for any significant time'. Cherchi et al. (1988) also note the presence of a cryptobiontic foraminiferan within the test of Orbitolina sp. in material from the Albian of Sinai, Egypt. They were also noted in borings within intraclasts. Channels constructed by the cryptobiontic foraminiferan cross the cortex of the larger foraminiferan as well as its sediment fill, indicating that these forms penetrated tests of dead specimens and were undoubtedly hermitic.

A foraminiferan with a comparable habit was described by Banner (1971). Planorbulinopsis parasitica is an endoparasite of Alveolinella quoii. Unlike $T$. canicularia, it does not bore right into the centre of the larger foram that it inhabits, but creates crypt similar to that created by Cymbulapora tabellaeformis. As in this species, a number of excavations ramify from the central cavity into the test of the host. The point of entry into the host is fairly constant, being either at an intercameral suture or the suture at the base of the apertural face. Evidence for the endoparasitic habit, with nutrition deriving from the host's protoplasm, including any symbionts present, and the skeletal material of the test wall, comes from the small size of the entrance hole compared with that of the crypt and its inhabitant. Banner (1971) does suggest that $P$. parasitica must be capable of independent utilization of externally available nutrients, at least in the early stages of its ontogeny. Other than this, however, he gives little evidence of the life association of the two Foraminifera involved. An alternative explanation of the association may parallel that proposed by Baumfalk et al. (1982) for the T. canicularia/Orbitoides association: that the smaller foraminiferan exploits the refuge afforded by the test of the dead host and may even mimic its original life habit.

Todd (1965) described a species of Rosalina that attaches to bivalve shells. This foraminiferan retains the test but creates attachment scars on the bivalve shell. These are circular depressions that penetrate both the periostracum and the mineralized shell beneath. The scars may perforate the host shell completely, resulting in a secretory response from the irritated bivalve mantle, which was clearly alive at the time of the association. This could be seen as suggesting that the foraminiferans were truly parasitic, though no evidence of trophic utilisation is given.

An unequivocal example of a foraminiferan that lives in a similar way to that described by Todd (1965) and which does undoubtedly obtain nutriment from the host, is the species Cibicides refulgens that lives epibiontically on Arctic scallops as described by Alexander \& DeLaca (1987). They showed, with the use of radioactively-labelled amino acids, that the foram is capable of exploiting the free amino acids from the host's extrapallial fluid. It does this by the erosion of the shell beneath the point of attachment of the test. The tunnels created, which extend into the shell of the mollusc from the pit immediately below the test, were investigated with the use of resin infill techniques. Unlike the excavations made by $V$. alabamensis, there is no inner lining of calcareous material to the tunnels. The borings do not seem to follow any innate lines of weakness in the shell, and the foraminiferan's cytoplasm can control both the extent and the direction of the dissolution process (Alexander \& DeLaca 1987). This particular foram does not only feed parasitically, but also employs its pseudopodia in suspension feeding and grazing off the surface of the scallop shell. Pseudopodial feeding is augmented by the addition of agglutinated tubes whcih extend from the pit below the test. These serve to surround the pseudopodia which can extend for millimeters from the test, until they become naked in their food collecting capacity. The authors postulate that these tubes may protect the pseudopodia from predation from grazers that also inhabit the shell surface. Of these, tanaid crustaceans were observed to feed on the unprotected pseudopodia and the distal ends of pseudopodia that were actively involved in feeding.

The examples discussed above show that several Foraminifera can not only bore into calcareous substrates, but that they often do so in a purposeful way in respect to the direction of boring and the attainment of the resource required. The ability to bore seems to have been developed independently in a variety of lineages, probably all with the same initial purpose: secure attachment to the substrate coupled with protection from the vicissitudes of the environment. This has subsequently become specialized to include a feeding role in certain cases. Of the foraminiferans that become entombed in the substrate, all retain the test, although the later stages of growth are liable to become highly variable in form depending on the substrate involved. A number of problems would repay further study, such as the method of calcite dissolution; whether the calcite removed is then utilized for the construction of the test of the foram; the nature of the association (hermitism or endoparasitism) between the small Foraminifera and their larger 'host', and whether such species are parasites for the whole of the life-cycle or only part of it.

\section{ACKNOWLEDGEMENTS}

John Todd first noticed the association of the collar with the boring, and selected many excellent examples during the course of his work on bioimmuration. David Griffiths and Geraint Hughes helped with photographic work.

\section{Manuscript received September 1992 \\ Manuscript accepted February 1993}

\section{REFERENCES}

Alexander, P.S. \& DeLaca, T.E. 1987. Feeding adaptations of the foraminiferan Cibicides refulgens living epizoically and parasitically on the Antactic scallop Adamussium colbecki. Biol. Bull, 173, 136-159.

Banner, F.T. 1971. A new genus of the Planorbulinidae, an 
endoparasite of another Foraminifera. Rev. Espan. Micropal. 3, 113-128.

Baumfalk, Y.A., Fortuin, A.R. \& Mok, R.P. 1982. Talpinella cunicularia n.gen., n.sp., a possible foraminiferal parasite of Late Cretaceous Orbitoides. J. Foram. Res. 12, 185-196.

Bernard-Dumanois, A. \& Delance, J.-H. 1983. Microperforations par algues et champignons sur les coquilles des 'Marnes a Ostrea acuminata' (Bajocian Superieur) de Bourgogne (France), relations avec le mileu et utilisation paléobathymetrique. Géobios, 16, 419429.

Boekschoten, G.J. 1966. Shell borings of sessile epibiontic organisms as palaeoecological guides (with examples from the Dutch coast). Palaeogeography, Palaeoclimatol. Palaeoecol. 2, 333-379.

Cherchi, A. \& Schroder, R. 1991. Perforations branchués dues à des Foraminifères cryptobiotique dans des coquilles actuelles et fossiles. C.R. Acad. Sci. Paris, Ser. II, 312, 111-115.

Cherchi, A., Kuss, A. \& Schroeder, R. 1988. Foraminiferi criptobionti in gusci di Orbitolina e in bio- e litoclasti dell'Abiano di Gebel Maghara (Penisola del Sinae, Egitto). Boll. Mus. reg. Sci. nat. Torino, 1990; iv Simp. Ecol $\mathcal{E}$ Paleorl. Communita bentoniche, sorrento $1988,151-174$.

DeLaca, T.E. \& Lipps, J.H. 1972. The mechanism and adaptive significance of attachment and substrate pitting in the Foraminiferan Rosalina globularis d'Orbigny. J. Foram. Res. 2, 6872.

Häntzschel, W. 1975. Trace Fossils and Problematica, 2nd edition In: Teichert, C. (Ed.) Treatise on Invertebrate Paleontology, Pt. W, Miscellanea, Supplemtnt 1, xxi+ 269pp., 110 figs. Univ Kansas Press.

Heron-Allen, E. 1915. Contributions to the study of the bionomics and reproduction processes of the Foraminifera. Phil. Trans. Roy. Soc. London, ser B, 206, 227-279.

Higazi, F. 1985. Kleinfaunen aus dem Oberjura des spanischen Keltiberikums mit spezieller Berücksichtigung der Paläoökologie. Arb. Inst. Geol. Palaont. Univ. Stuttgart, n.ser. 82,
127-159.

Kornmann, P. 1959. Die heterogene Gattung Gomontia. 1. Der sporoangiale Anteil, Helgol. wiss. Meeresunters, 6, 229-238.

Mayoral, E. 1988. Microperforaciones (Thallophyta) sobre bivalvia del Plioceno del Bajo Guadalquiver. Importancia Paleoecologica. Estudios geol. 44, 301-316.

Matteucci, R. 1974. Cymbaloporella tabellaeformis (Brady), Foraminifero endolitico del Mar Rosso. Geologica Romana, 13, 29 43.

Matteucci, R. 1980. Osservazioni sul foraminifero endolitico Cymbaloporella tabellaeformis (Brady) nell'atollo di Malé (North Malé), isole Maldive. Geologica Romana, 19, 267-274.

Poag, C.W. 1969. Dissolution of molluscan calcite by the attached Foraminifer Vasiglobulina, a new Genus (Vasiglobulininae, new Subfamily). Tulane Stud. Geol. Paleontol. 7, 45-89.

Poag, C.W. 1971. Notes on the morphology and habit of Vasiglobulina alabamensis (Foraminiferida). J. Paleontol. 45, 961962.

Pohowsky, R.A. 1978. The boring ctenostome Bryozoa: taxonomy and paleobiology bnased on cavities in calcareous substrata. Bull Amer. Paleont. No.301, 73, 1-192.

Pozaryska, K. \& Voigt, E. 1985. Bryozoans as substratum fossil fistulose Foraminifera (Fam. Polymorphinidae). Lethaia, 18, 155165.

Todd, R. 1965. A new Rosalina (Foraminifera) parasitic on a bivalve: Deep Sea Res. 12, 831-837.

Venec-Peyre, M.-T. 1985. Le rôle de certains Foraminifères dans la bioérosion et la sédimentogenèse. C.R. Acad. Sci. Paris, Ser. II, 300, 83-88

Venec-Peyre, M.-T. 1987. Boring Foraminifera in French Polynesian coial reefs. Coral Reefs, 5, 205-212.

Vogel, K., Golubic, S. \& Brett, C.E. 1987. Endolith associations and their relation to facies distribution in the Middle Devonian of New York State, U.S.A. Lethaia, 20, 263-290. 